\title{
Bir üniversite hastanesi dahiliye polikliniğine başvuranlarda sağlık okuryazarlığı düzeyi ve ilişkili etmenler
}

\author{
Health literacy level and associated factors in internal medicine polyclinic of a \\ university hospital \\ Nevzat Atalay Çelikyürek, Nurhan Meydan Acımış, Betül Özcan
}

Gönderilme tarihi:06.08.2019

Kabul tarihi:08.01.2020

\begin{abstract}
Özet
Amaç: Pamukkale Üniversitesi Tıp Fakültesi İç Hastalıkları Polikliniğine başvuran hastalarda sağlık okuryazarlığı düzeyinin ve ilişkili etmenlerin belirlenmesidir.

Gereç ve yöntem: Kesitsel tipte olan bu çalışma Ağustos 2018 tarihinde yapıldı. Araştırmanın evrenini Pamukkale Üniversitesi Tıp Fakültesi İç Hastalıkları Polikliniklerine başvuran hastalar oluşturmaktadır. Araştırmanın bağımlı değişkeni TSOY-32 Ölçeği ile ölçülen sağlık okuryazarlığı düzeyi olup bağımsız değişkenleri ise sosyodemografik özellikler, sağlık durumu ve sağlık hizmet kullanım özellikleridir.

Bulgular: Araştırmaya 388 kişi katıldı. Katılımcıların yaş ortalaması 42,14ะ16,47, öğrenim düzeyi \%36,9'u yüksekokul/üniversite mezunu ve üzeri idi. Katılımcıların sağlık problemleri ile ilgili ilk başvurdukları sağlık

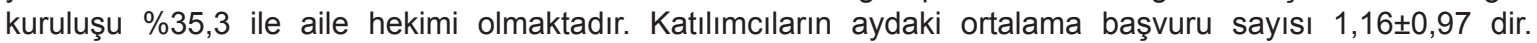
Katılımcılar kendi sağlık düzeylerini; mükemmel $(\% 3,1)$, oldukça iyi $(\% 12,6)$, iyi $(\% 37,9)$, fena değil $(\% 35,3)$, kötü $(\% 11,1)$ olarak algılamaktadır. \%55,2'si kronik bir hastalığı olduğunu, \%59,3'ü düzenli ilaç kullanmasını gerektiren bir hastalığa sahip olduğunu belirtti. TSOY-32 Ölçeğinden alınan ölçek indeks puanı ortalaması $31,18 \pm 9,20$ bulundu. Sağlık okuryazarlığı düzeyini kategorik olarak sınıflandırdığımızda $\% 25,8$ yetersiz, $\% 34,5$ sorunlu-sınırlı, \%27,3 yeterli, \%12,4 olarak tespit edildi. Medeni durum, öğrenim düzeyi, çalışma durumu, kendi sağlık düzeyi algısı, kronik hastalık varlığı ile sağlık okuryazarlığı düzeyleri arasında istatistiksel olarak anlamlı bir farklılık saptandı $(p<0,001)$.

Sonuç: Bu çalışmada katılımcıların daha çoğunun $(\% 34,5)$ sorunlu/sınırlı sağlık okuryazarlığı düzeyine sahip olduğu ve sağlık okuryazarlığı düzeylerinin; yaş, medeni durum, en uzun süre yaşanılan yer, gelir algısı durumu, kendi sağlık düzeyi algısı gibi değişkenlerden etkilendiği saptanmıştır.
\end{abstract}

Anahtar kelimeler: Sağlık okuryazarlığı, sağlığın geliştirilmesi, poliklinik, ölçek.

Çelikyürek NA, Meydan Acımış N, Özcan B. Bir üniversite hastanesi dahiliye polikliniğine başvuranlarda sağlık okuryazarlığı düzeyi ve ilişkili etmenler. Pam Tıp Derg 2020;13:258-266.

\begin{abstract}
Purpose: The aim of this study is to determine the health literacy level and related factors in patients admitted to the Internal Medicine Polyclinic of Pamukkale University Faculty of Medicine.

Materials and methods: This cross-sectional study was performed in August 2018. The population of the study consisted of patients who applied to Internal Medicine Polyclinics. The dependent variable is the health literacy level measured by TSOY-32 Scale and the independent variables are sociodemographic, health status and health service use characteristics.

Results: In total, 388 participants median age was $42.14 \pm 16.47,36.9 \%$ of them graduated college or above. The first health institution to which the participants for health problems is family physicians with $35.3 \%$. The average number of applications to any health institution in the month was $1.16 \pm 0.97$. The percentages of the participants' perceptions of their health level were excellent, quite good, good, not bad, and bad, respectively $3.1,12.6,37.9,35.3,11.1$. While $55.2 \%$ of the participants had a chronic disease, $59.3 \%$ had a disease requiring regular medication. The average index score of the TSOY-32 Scale was $31.18 \pm 9.20$. When the health literacy level is categorically classified, $25.8 \%$ insufficient, $34.5 \%$ problematic-limited, $27.3 \%$ sufficient, $12.4 \%$ excellent health literacy levels were determined.

Conclusions: In this study, it was found that the majority of the participants were at the problem-limited health literacy level (34.5\%) and the health literacy levels of the participants were related to some variables such as age, marital status, long-term place of residence, income perception status and their own health level perception.
\end{abstract}

Key words: Health literacy, health promotion, polyclinic, scale.

Nevzat Atalay Celikyürek, Arş. Gör. Dr. Pamukkale Üniversitesi Tıp Fakültesi Halk Sağlığı Anabilim Dalı, Denizli, Türkiye, e- posta: atalaycelikyurek@gmail.com (orcid.org/0000-00019731-8880) (Sorumlu Yazar)

Nurhan Meydan Acımış, Doç. Dr. Pamukkale Üniversitesi Tıp Fakültesi Halk Sağlığı Anabilim Dalı, Denizli, Türkiye, e- posta: nurhan88@ hotmail.com (orcid.org/0000-0001-9616-1033)

Betül Özcan, Arş. Gör. Dr. Pamukkale Üniversitesi Tıp Fakültesi Halk Sağlığı Anabilim Dalı, Denizli, Türkiye, e- posta: drbetulozcan@gmail.com (orcid.org/0000-0002-6078-8448) 
Çelikyürek NA, Meydan Acımış N, Özcan B. Health literacy level and associated factors in ınternal medicine polyclinic of a university hospital. Pam Med J 2020;13:258-266.

\section{Giriş}

Sağlık okuryazarlığı yaşam boyunca hayat kalitesini korumak veya iyileştirmek için sağlık bakımı, hastalık önleme ve sağlığın teşviki ve geliştirilmesi ile ilgili günlük yaşamda kararlar verebilme ve kararlar almak için sağlık bilgilerine erişme, anlama, değerlendirme ve uygulama konularında bilgi, motivasyon ve yetkinlikleri içerir [1]. Ülkemizde ise, Sağlık Bakanlığı Temel Sağlık Hizmetleri Genel Müdürlüğü Sağlığın Teşviki ve Geliştirmesi Sözlüğü'nde yer alan tanıma göre, bireylerin kendi sağlığı ve toplum sağlığını iyileştirmek amacıyla, yaşam tarzı ve koşullarını değiştirmede gerekli bilgi, beceri, kendine güven düzeyine ulaşmasıdır [2].

Son yıllarda sağlık okuryazarlığı dünya genelinde büyük ilgi görmüştür. 21. yüzyıla ait bilgi toplumları, sağlıkta karar verme ikilemi ile karşı karşıyadır. İnsanlar, karmaşık yaşam ortamları ve sağlık hizmetleri sistemleri aracılığıyla sağlıklı yaşam tarzı seçimlerini yapmakta giderek daha fazla zorlanmakta ve bu görevlerin yerine getirilmesi konusunda ne yazik ki iyi hazırlanmamakta ya da desteklenmemektedirler. Modern olarak nitelendirilen toplumlar sağlıksız yaşam tarzlarını aktif olarak pazarlamakta, sağlık sistemleri en iyi eğitimli insanlar için bile git gide daha zor olmaktadır. Ayrıca eğitim sistemleri insanlara bilgi sağlamak için bilgiye erişmek, anlamak, değerlendirmek ve kullanmak için yeterli becerilere sahip olmakta yetersiz kalmaktadır [3].

Sağlık okuryazarlığı düzeyi yüksek olanlar, ekonomik refah düzeyinde aktif olarak yer alırlar, daha yüksek kazanç ve istihdama sahiptirler, toplumsal faaliyetlere daha fazla katkıda bulunurlar ve iyi bir sağlık ve esenlik düzeyindedirler. Ancak sınırlı ve düşük sağlık okuryazarlık düzeyleri sağlığı önemli bir ölçüde etkiler. Bu düzeydeki kişilerin sağlığı teşvik edici yön ve erken tanıyı önemseyen faaliyetlere katılımı az iken, sigara içme ve daha çok iş kazası yaşama gibi riskli durumları yaşama durumu daha sıktır. Daha kötü kronik hastalık yönetimi, daha çok hastane başvurularına sebep olur. Sınırlı sağlık okuryazarlık düzeyi mevcut sağlık eşitsizliklerini daha fazla arttırabilmektedir.
Sağlık okuryazarlığı düzeyi düşük olan kişiler genellikle daha düşük eğitim seviyesine sahiptirler (yaşlılar, göçmenler vb.) ve çeşitli kamusal yardımlara bağımlıdırlar.

Kişisel sağlık okuryazarlığı becerilerini ve yeteneklerini inşa etmek hayat boyu devam eden bir süreçtir. Hiç kimse tamamen sağlık okuryazarı değildir. Yüksek eğitimli bireyler bile özellikle hayat kalitelerini düşüren sağlık durumları karşısında mevcut sağlık sistemlerini çok karmaşık bulabilirler. Sağlık okuryazarlığı ile ilgili kapasite ve yeterlilik, şartlara, kültüre ve ortama göre değişir. İletişim becerileri, sağlık konularının bilgisi, kültür ve sağlık hizmetlerinin durumu, halk sağlığı ve diğer ilgili sistemlerin bilgilerinin elde edildiği, kullanıldığı yerlerin spesifik özellikleri yer alır. Sınırlı sağlık okuryazarlığı, yüksek sağlık maliyetleri ile ilişkilidir. Örneğin, Kanada'da 2009 yılında toplam sağlık hizmetleri bütçesinin yaklaşık \%3 ila 5'ini oluşturan 8 milyar ABD dolarından daha pahalıya mal olmuştur. 1998'de ABD Ulusal Yaşlılık Akademisi, sınırlı sağlık okuryazarlığı düzeylerinden kaynaklanan ek sağlık hizmet maliyetlerini 73 milyar dolar olarak tahmin etmiştir. Avrupa sağlık sistemleri için henüz karşılaştırmalı bir veri bulunmamakla birlikte, sınırlı ve düşük sağlık okuryazarlık düzeylerinin Avrupa refah devletlerinde sağlık sistem kaynaklarını boşaltması beklenmektedir [4]. Türkiye'yi temsil eden sağlık okuryazarlığı ile ilgili ilk araştırma 2014 yılında Sağlık ve Sosyal Hizmet Çalışanları Sendikası tarafından Avrupa Sağlık Okuryazarlığı Anketi (HLS-EU) kullanılarak Türkiye'yi temsil eden 12 bölgedeki 23 ilde rastgele seçilen 4924 erişkin kişinin katılımı ile gerçekleştirilmiştir [5].

Kronik hastalığı olan bireylerde sağlık okuryazarlığı ayrı bir önem taşımaktadır. Kronik hastalıkların önlenmesi ve yönetimi aile hekimlerinin, iç hastalıkları, geriatri ve diğer ilgili uzmanlık alanlarında uzman olan hekimlerin ve hemşirelerin görevleri arasında olup kronik bakım yönetimi uygulamada ciddi değişim gerektirmektedir. Kronik hastalık ya da hastalıklara sahip kişilerde yüksek sağlık okuryazarlığı düzeyleri hastalık yönetimi açısından önem taşımaktadır [6]. Bu çalışmanın amacı ise herhangi bir sebeple 
Pamukkale Üniversitesi Hastanesi İç Hastalığı Polikliniklerine başvuran ve okuryazar olan bireylerde sağlık okuryazarlığı düzeylerinin ve ilişkili faktörlerin belirlenmesidir.

\section{Gereç ve yöntem}

Analitik kesitsel tipteki bu araştırma Ağustos 2018 tarihinde yapıldı. Araştırma evrenini Pamukkale Üniversitesi Dahiliye Polikliniklerine herhangi bir nedenle başvuran ve okuryazar olan hastalar oluşturmaktaydı.

Araştırmanın örneklem büyüklüğü evrendeki birey sayısı bilinmeyen örnek büyüklüğü formülüne göre; $\left(n=t^{2}\right.$.p.q/ $\left./ d^{2}\right)$ kullanılarak $\% 95$ güven aralığında, $\% 5$ sapma ve $\% 50$ bilinmeyen prevalans değeri ile "384" olarak hesaplandı.

Verilerin toplanmasında anket formu kullanıldı. Anket formu, katılımcıların sosyodemografik özelliklerini, sağlık durumunu ve sağlık hizmetlerini kullanımını sorgulayan 13 soruyu ve sağlık okuryazarlık durumlarını ölçen 32 soruluk Türkiye Sağlık Okuryazarlığı Ölçeği32'yi (TSOY-32) içermektedir. Araştırmanın bağımlı değişkeni TSOY-32 Ölçeği ile belirlenen sağlık okuryazarlığı düzeyidir. Araştırmanın bağımsız değişkenleri ise:

-Sosyodemografik ve sosyoekonomik özellikler (yaş, cinsiyet, medeni durum, öğrenim düzeyi, çalışma durumu, sağlık güvencesinin türü, en uzun süre yaşadığı yerleşim yeri, gelir algısı). Yaş gruplarının örneklem içinde adil temsiliyetini sağlayabilmek için 2017 TÜíK nüfus verileri kullanıldı [7].

\section{-Kendi sağlığını nasıl değerlendirdiği}

-Sağlık durumu ile ilgili özellikler (kronik hastalığın olup olmama durumu, düzenli ilaç kullanımını gerektiren bir hastalık olup olmama durumu, hastalık durumunda ilk başvurduğu sağlık kuruluşu, ayda ortalama kaç kere sağlık kuruluşuna başvurduğu)

TSOY-32 Ölçeği HLS-EU Çalışması Kavramsal Çerçevesi (HLS-EU CONSORTIUM, 2012) temel alınarak geliştirilmiş ve ölçeğin geçerlilik ve güvenilirlik çalışması 2016 yılında Okyay ve ark. tarafından yapılmıştır. Ölçeğin iç tutarlılık analizi sonucu Cronbach's alfa katsayısı 0,927 olarak hesaplanmıştır. TSOY-32 Ölçeği toplam puanı formül (indeks=(ortalama-1) x(50/3)) yardımıyla hesaplanmakta ve $0-50$ puan aralığında değişmektedir. TSOY-32 ölçeğinden alınan toplam puan dört kategoride sınıflandırılmaktadır ve $0-25$ puan yetersiz sağlık okuryazarlığı, >25-33 puan sorunlu-sınırlı sağlık okuryazarlığı, >33-42 puan yeterli sağlık okuryazarlığı ve $>42-50$ puan ise mükemmel sağlık okuryazarlığı olarak değerlendirilmektedir [8].

VerilerSPSS 17.0 paket programı kullanılarak analiz edildi. İstatistiksel değerlendirmede isimsel değişkenlerin analizinde ki-kare testi, sayısal değişkenlerin değerlendirilmesinde spearman korelasyon analizi kullanıldı. Sağlık okuryazarlığı düzeyine etki eden değişkenleri saptamak için lojistik regresyon analizi uygulandı. İstatistiksel anlamlılık düzeyi $p<0,05$ olarak kabul edildi.

Araştırma için gerekli olan 26/07/2018 tarihli 60116787-020/50510 sayılı Pamukkale Üniversitesi Girişimsel Olmayan Klinik Araştırmalar Etik Kurulu'ndan onay ve Pamukkale Üniversitesi Hastanesi Başhekimliği idari izni alındı. Araştırmayı kabul eden hastalara anket uygulandı.

\section{Bulgular}

Araştırmaya 388 kişi katılmış olup; yaş

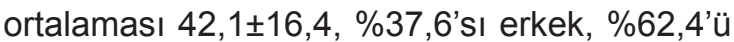
kadın, \%58,1'i evli, \%36,9'u yüksekokul/ üniversite mezunudur. Yaş grupları; 18-34 \%37,6 (146), 35-49 \%29,1 (113), 50-64 \%21,4 (83), 65 yaş ve üzeri \%11,9 (46) dir. Yaş ortalaması 42,14 $\pm 16,47$ min18- max 88 dir. Ayda ortalama başvuru sayısı min $0-\max 1,16$ ortalama $0,97 \pm 0,404$ dür (Tablo 1 ).

Yaş ile sağlık okuryazarlığı arasında önemli bir farklılık mevcuttur $(p<0,001)$. Dul/ Boşanmış/ Ayrı grubu ile Yüksekokul/ Üniversite Mezunu ve üzeri gruplarının sağlık okuryazarlık düzeyi de diğer gruplara oranla fazla bulunmuştur $(p<0,001)$ (Tablo 3).

Araştırmaya katılanların çalışma durumlarına göre; \%36,6 sı çalışan, \%18,8'i ise emeklidir. $\% 47,2$ 'si SSK güvencesinde iken, $\% 52,6$ 's। en uzun süre yaşadıkları yerleşim birimlerini il merkezi olduğunu, \%43,8'i algılanan gelir durumunu geliri gidere eşit olduğunu belirtmiştir (Tablo 1). Çalışan durumuna göre halen çalışanların $(p<0,001)$, en uzun süre yaşadığı yerin il olduğunu belirtenlerin $(p=0,004)$ ve geliri giderinden fazla olanların sağlık okuryazarlık düzeyi yüksek saptanmıştır $(p=0,001)$ (Tablo 
3). Katılımcıların herhangi bir sağlık kuruluşuna başvuru ortalaması ayda 1,16 $\pm 0,97 \quad(p=0,404)$ dir. Araştırmaya en fazla katılım genel dahiliye $(\% 32,0)$, endokrin (\%28) poliklinik başvuruları sırasında olmuştur. Herhangi bir hastalık durumunda katılımcıların ilk başvurdukları sağlık kuruluşları; \%35,3 aile hekimi, \%27,6 devlet hastaneleri ve $\% 27,6$ üniversite hastaneleridir (Tablo 1). Endokrin ve Genel Dahiliye polikliniklerine başvuranların sağlık okuryazarlık düzeyleri yüksek saptanmıştır $(p=0,006)$ (Tablo 3).

Hastaların kendi sağlık durumlarını değerlendirmesi istendiğinde; \%37,9'u iyi olduğunu ifade ederken, \%35,3'ü fena değil yanıtını vermiştir. \%55,2 bir ya da daha fazla kronik hastalığa sahiptir. \%59,3 ü de düzenli ilaç kullanmaktadır (Tablo 1). Katılımcılardan kendi sağlık düzeyini fena değil ve iyi olarak değerlendirenlerin sağlık okuryazarlık düzeyi daha yüksektir $(p<0,001)$. Kronik hastalığa sahip olanların sağlık okuryazarlık düzeyi yüksek iken $(p<0,001)$, düzenli ilaç kullanımı ile sağlık okuryazarlığı arasında anlamlı farklılık saptanmamıştır ( $p=0,092)$ (Tablo 3). Araştırmaya katılan 388 kişinin sağlık okuryazarlık düzeyi için kullanılan TSOY-32 ölçeğinin indeks puan ortalaması minimum 5,07- maksimum 50,0 iken

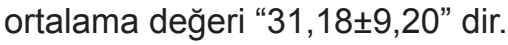

Araştırmaya katılanların TSOY-32 ölçeğine göre sağlık okuryazarlığı düzeyleri; \%25,8 yetersiz, \%34,5 sorunlu/sınırlı, \%27,3 yeterli ve \%12,4 mükemmel sağlık okuryazarlığı düzeyindedir (Tablo 2).

Yaş ile TSOY-32 ölçeğinden aldıkları indeks puanları Spearman korelasyon analizine göre negatif yönde orta derecede anlamlı korelasyon saptanmıştır ( $r /$ rho-0,364) $(p<0,001)$.

Sağlık okuryazarlığına etki eden faktörleri araştırmak için yapılan regresyon analizinde yaş (O.R 0,92; \%95 GA 0,97-0,978; $p<0,001)$, en uzun süre yaşanılan yerin il olması (O.R 4,896; \%95 GA 1,614-14,848; $p=0,005)$, geliri giderinden fazla olması (O.R 3,098; \%95 GA $1,571-6,11 ; p=0,001)$ durumu etkili bulunmuştur. Algılanan sağlığını fena değil (O.R 4,120; \%95 GA 1,374-12,354; $p=0,012)$, oldukça iyi (O.R 4,120; \%95 GA 1,374-12,354; $p=0,012$ ) ve mükemmel (O.R 29,687; \%95 GA 4,341203,00; $p=0,001$ ) olarak belirtenlerin sağlık okuryazarlığı puan ortalamaları regresyon modelinde anlamlılık göstermektedir (Tablo 4).

\section{Tartışma}

Son yıllarda sağlık okuryazarlığı kavramı ülkemizde de önem kazanmaktadır. Yaptığımız çalışmada TSOY-32 ölçeği kullanılarak herhangi bir sebeple dahiliye polikliniğine başvuran hastaların sorunlu-sınırlı $(31,18)$ sağlık okuryazarlığı düzeyinde olduğunu saptadık. Sorensen ve ark.'nın yaptığı çalışmada, sekiz Avrupa ülkesinde sağlık okuryazarlığını 33,78 olarak tespit etmiştir [1]. Ülkemizde, Okyay ve Abacıgil yaptığı araştırmada sağlık okuryazarlığı puan ortalamasını "29,5" olarak, Tanrı̈ver ve ark. ise "30,4" olarak bulmuştur [5, 8]. Araştırmamızda, dahiliye polikliniğine başvuran hastaların puan ortalamaları $(31,18)$ yukarıdaki verilen iki araştırmadaki puan ortalamasına benzerdir. Aynı zamanda hastaların \%25,8 yetersiz sağlık okuryazarlığı düzeyine sahip olduğu bulunmuştur. Sorensen ve ark.'nın çalışmasında ise katılımcıların \%12.4'ü yetersiz sağlık okuryazarlığı düzeyine sahiptiler [1]. Okyay ve Abacıgil'in çalışmasında bu oran $\% 27,2$, Tanrı̈ver ve ark.'nın çalışmasında ise $\% 24,5$ olarak belirtilmektedir [5, 8]. Bizim araştırma verilerimiz, Türkiye'de yapılan çalışmalara benzer olsa da, yetersiz sağlık okuryazarlığı oranı açısından bakıldığında Avrupa ülkelerinin gerisindedir. Araştırmamızda hastaların \%12,4'ünün mükemmel sağlık okuryazarlığı düzeyinde olduğu tespit edilmiştir. Sorensen ve ark'nın yaptıkları çalışmada bu oran \%16,5, Okyay ve Abacıgil'in çalışmasında $\% 5,8$, Tanrıöver ve ark.'nın çalışmasında ise $\% 7,5$ olarak bulunmuştur [1, 5, 8]. Mükemmel sağlık okuryazarlığı düzeyinin yukarıdaki diğer araştırmalardan yüksek olmasını, üniversite hastanesi başvurularına ve başvuran profiline (yüksek eğitim düzeyi) bağlayabiliriz. Sorensen ve ark., Tanrı̈ver ve ark., Okyay ve Abacıgil'in çalışmalarında eğitim düzeyi ile birlikte sağlık okuryazarlığı düzeyinin arttığı belirtilmektedir [1, 5, 8]. Bizim çalışmamız eğitim düzeyi ile sağlık okuryazarlığı ilişkisinin anlamlı olarak farklı olduğunu doğrulamaktadır $(p<0,001)$. Sorensen ve ark. yaş arttıkça ve gelir düzeyi azaldıkça da sağlık okuryazarlığı düzeyinin düşmekte olduğunu ifade etmişlerdir [1]. Bu sonuç araştırmamız için benzer bulunmuştur. Çalışmamızda sağlık okuryazarlığını etkileyen 
Tablo 1. Katılımcıların sosyodemografik özellikleri, sağlık durumları ve sağlık hizmet kullanımları.

\begin{tabular}{|c|c|c|}
\hline & $\mathbf{n}$ & $\%$ \\
\hline \multicolumn{3}{|l|}{ Cinsiyet } \\
\hline Erkek & 146 & 37,6 \\
\hline Kadın & 242 & 62,4 \\
\hline \multicolumn{3}{|l|}{ Medeni Durum } \\
\hline Evli & 225 & 58,1 \\
\hline Bekar & 121 & 31,3 \\
\hline Dul / Boşanmış / Ayrı & 41 & 10,6 \\
\hline \multicolumn{3}{|l|}{ Öğrenim Düzeyi } \\
\hline Okuryazar & 18 & 4,6 \\
\hline İlkokul Mezunu & 91 & 23,5 \\
\hline Ortaokul Mezunu & 41 & 10,6 \\
\hline Lise Mezunu & 95 & 24,5 \\
\hline Yüksekokul / Üniversite Mezunu Ve Üzeri & 143 & 36,9 \\
\hline \multicolumn{3}{|l|}{ Çalışma Durumu } \\
\hline Emekli & 73 & 18,8 \\
\hline Çalışmıyorum & 173 & 44,6 \\
\hline Çalışıyorum & 142 & 36,6 \\
\hline \multicolumn{3}{|l|}{ Sağlık Güvencesi } \\
\hline Emekli Sandığı & 101 & 26,0 \\
\hline SSK & 183 & 47,2 \\
\hline Bağkur & 64 & 16,5 \\
\hline Yeşilkart & 16 & 4,1 \\
\hline Özel Sağlık Sigortası & 9 & 2,3 \\
\hline Yok & 14 & 3,6 \\
\hline \multicolumn{3}{|l|}{ En Uzun Süre Yaşadığı Yer } \\
\hline ì & 204 & 52,6 \\
\hline İlçe & 96 & 24,7 \\
\hline Kasaba & 37 & 9,5 \\
\hline Köy & 51 & 13,1 \\
\hline \multicolumn{3}{|l|}{ Gelir Algısı } \\
\hline Gelir Giderden Az & 142 & 36,6 \\
\hline Gelir Gidere Eşit & 170 & 43,8 \\
\hline Gelir Giderden Fazla & 76 & 19,6 \\
\hline \multicolumn{3}{|l|}{ Başvurulan Poliklinik } \\
\hline Endokrin & 109 & 28,1 \\
\hline Gastroenteroloji & 10 & 2,6 \\
\hline Genel Dahiliye & 124 & 32,0 \\
\hline Hepatoloji & 4 & 1,0 \\
\hline Nefroloji & 14 & 3,6 \\
\hline Romatoloji & 68 & 17,5 \\
\hline Diğer & 59 & 15,2 \\
\hline \multicolumn{3}{|l|}{ İlk Başvurulan Sağlık Kuruluşu } \\
\hline Aile Hekimi & 137 & 35,3 \\
\hline Devlet Hastanesi & 107 & 27,6 \\
\hline Üniversite Hastanesi & 107 & 27,6 \\
\hline Özel Hastane & 35 & 9,0 \\
\hline Özel Muayenehane & 2 & 0,5 \\
\hline \multicolumn{3}{|l|}{ Sağlık Değerlendirmesi } \\
\hline Mükemmel & 12 & 3,1 \\
\hline Oldukça İyi & 49 & 12,6 \\
\hline İyi & 147 & 37,9 \\
\hline Fena Değil & 137 & 35,3 \\
\hline Kötü & 43 & 11,1 \\
\hline \multicolumn{3}{|l|}{ Kronik Hastalık } \\
\hline Evet & 214 & 55,2 \\
\hline Hayır & 174 & 44,8 \\
\hline \multicolumn{3}{|l|}{ Düzenli İlaç Kullanımı Gerektiren Hastalık } \\
\hline Evet & 230 & 59,3 \\
\hline Hayır & 158 & 40,7 \\
\hline
\end{tabular}


Tablo 2. Katııımcıların sağlık okuryazarığı düzeyleri.

\begin{tabular}{lll}
\hline & $\mathbf{n}$ & $\%$ \\
\hline Sağlık Okuryazarlık Düzeyi & & \\
Yetersiz Sağlık Okuryazarlığı & 100 & 25,8 \\
Sorunlu - Sınırlı Sağlık Okuryazarlığı & 134 & 34,5 \\
Yeterli Sağlık Okuryazarlığı & 106 & 27,3 \\
Mükemmel Sağlık Okuryazarlığı & 48 & 12,4 \\
\hline
\end{tabular}

Tabıo 3. Katıımcıların sağlık okuryazarlığı düzeyleriyle ilişkili etmenler.

\begin{tabular}{|c|c|c|c|c|c|c|c|c|c|}
\hline & \multicolumn{8}{|c|}{ Sağlık Okuryazarlığı Düzeyi } & \multirow{3}{*}{$p$} \\
\hline & \multicolumn{2}{|c|}{ Yetersiz SOY } & \multicolumn{2}{|c|}{$\begin{array}{l}\text { Sorunlu - Sınırlı } \\
\text { sOY }\end{array}$} & \multicolumn{2}{|c|}{$\begin{array}{l}\text { Yeterli Sağlık } \\
\text { SOY }\end{array}$} & \multicolumn{2}{|c|}{$\begin{array}{l}\text { Mükemmel } \\
\text { SOY }\end{array}$} & \\
\hline & $\mathbf{n}$ & $\%$ & $\mathbf{n}$ & $\%$ & $\mathbf{n}$ & $\%$ & $\mathbf{n}$ & $\%$ & \\
\hline \multicolumn{10}{|l|}{ Cinsiyet } \\
\hline Erkek & 30 & 20,5 & 52 & 35,6 & 39 & 26,7 & 25 & 17,1 & \multirow[t]{2}{*}{0,076} \\
\hline Kadın & 70 & 28,9 & 82 & 33,9 & 67 & 27,7 & 23 & 9,5 & \\
\hline \multicolumn{10}{|l|}{ Medeni durum } \\
\hline Evli & 57 & 25,3 & 92 & 40,9 & 54 & 24,0 & 22 & 9,8 & \multirow{3}{*}{$<0,001$} \\
\hline Bekar & 20 & 16,5 & 28 & 23,1 & 48 & 39,7 & 25 & 20,7 & \\
\hline Dul/Boşanmış/ Ayrı & 23 & 56,1 & 14 & 34,1 & 3 & 7,3 & 1 & 2,4 & \\
\hline \multicolumn{10}{|l|}{ Öğrenim Düzeyi } \\
\hline Okuryazar & 14 & 77,8 & 3 & 16,7 & 1 & 5,6 & 0 & 0 & \multirow{5}{*}{$<0,001$} \\
\hline İlkokul Mezunu & 34 & 37,4 & 35 & 38,5 & 17 & 18,7 & 5 & 5,5 & \\
\hline Ortaokul Mezunu & 10 & 24,4 & 18 & 43,9 & 11 & 26,8 & 2 & 4,9 & \\
\hline Lise Mezunu & 16 & 16,8 & 39 & 41,1 & 24 & 25,3 & 16 & 16,8 & \\
\hline $\begin{array}{l}\text { Yüksekokul / Üniversite } \\
\text { Mezunu ve Üzeri }\end{array}$ & 26 & 18,2 & 39 & 27,3 & 53 & 37,1 & 25 & 17,5 & \\
\hline \multicolumn{10}{|l|}{ Çalışma Durumu } \\
\hline Emekli & 30 & 41,1 & 27 & 37,0 & 13 & 17,8 & 3 & 4,1 & \multirow{3}{*}{$<0,001$} \\
\hline Çalışmıyorum & 48 & 27,7 & 60 & 34,7 & 43 & 24,9 & 22 & 12,7 & \\
\hline Çalışıyorum & 22 & 15,5 & 47 & 33,1 & 50 & 35,2 & 23 & 16,2 & \\
\hline \multicolumn{10}{|l|}{ Sağlık Güvencesi } \\
\hline Emekli Sandığı & 17 & 16,8 & 35 & 34,7 & 28 & 27,7 & 21 & 20,8 & \multirow{6}{*}{0,144} \\
\hline Ssk & 55 & 30,1 & 59 & 32,2 & 49 & 26,8 & 20 & 10,9 & \\
\hline Bağkur & 15 & 23,4 & 29 & 45,3 & 15 & 23,4 & 5 & 7,8 & \\
\hline Yeşilkart & 4 & 25,0 & 4 & 25,0 & 7 & 43,8 & 1 & 6,3 & \\
\hline Özel Sağlık Sigortası & 3 & 33,3 & 3 & 33,3 & 2 & 22,2 & 1 & 11,1 & \\
\hline Yok & 6 & 42,9 & 4 & 28,6 & 4 & 28,6 & 0 & 0,0 & \\
\hline \multicolumn{10}{|l|}{ En uzun süre yaşadığı yer } \\
\hline ì & 43 & 21,1 & 76 & 37,3 & 62 & 30,4 & 23 & 11,3 & \multirow{4}{*}{0,004} \\
\hline İlçe & 22 & 22,9 & 33 & 34,4 & 27 & 28,1 & 14 & 14,6 & \\
\hline Kasaba & 12 & 32,4 & 6 & 16,2 & 11 & 29,7 & 8 & 21,6 & \\
\hline Köy & 23 & 45,1 & 19 & 37,3 & 6 & 11,8 & 3 & 5,9 & \\
\hline \multicolumn{10}{|l|}{ Gelir Algısı } \\
\hline Gelir Giderden Az & 46 & 32,4 & 55 & 38,7 & 28 & 19,7 & 13 & 9,2 & \multirow{3}{*}{0,001} \\
\hline Gelir Gidere Eşit & 41 & 24,1 & 62 & 36,5 & 43 & 25,3 & 24 & 14,1 & \\
\hline $\begin{array}{l}\text { Gelir Giderden } \\
\text { Fazla }\end{array}$ & 13 & 17,1 & 17 & 22,4 & 35 & 46,1 & 11 & 14,5 & \\
\hline
\end{tabular}


Tablo 3. Katılımcıların sağlık okuryazarlığı düzeyleriyle ilişkili etmenler. (devamı)

\begin{tabular}{|c|c|c|c|c|c|c|c|c|c|}
\hline \multicolumn{10}{|l|}{ Başvurulan Poliklinik } \\
\hline Endokrin & 27 & 24,8 & 45 & 41,3 & 26 & 23,9 & 11 & 10,1 & \multirow{7}{*}{0,006} \\
\hline Gastroenteroloji & 1 & 10,0 & 5 & 50,0 & 3 & 30,0 & 1 & 10,0 & \\
\hline Genel Dahiliye & 32 & 25,8 & 26 & 21,0 & 48 & 38,7 & 18 & 14,5 & \\
\hline Hepatoloji & 3 & 75,0 & 0 & 0,0 & 0 & 0,0 & 1 & 25,0 & \\
\hline Nefroloji & 3 & 21,4 & 9 & 64,3 & 2 & 14,3 & 0 & 0,0 & \\
\hline Romatoloji & 14 & 20,6 & 26 & 38,2 & 17 & 25,0 & 11 & 16,2 & \\
\hline Diğer & 20 & 33,9 & 23 & 39,0 & 10 & 16,9 & 6 & 10,2 & \\
\hline \multicolumn{10}{|l|}{$\begin{array}{l}\text { İlk Başvurulan Sağlık } \\
\text { Kuruluşu }\end{array}$} \\
\hline Aile Hekimi & 45 & 32,8 & 48 & 35,0 & 33 & 24,1 & 11 & 8,0 & \multirow{5}{*}{0,185} \\
\hline Devlet Hastanesi & 26 & 24,3 & 39 & 36,4 & 30 & 28,0 & 12 & 11,2 & \\
\hline Üniversite Hastanesi & 19 & 17,8 & 38 & 35,5 & 32 & 29,9 & 18 & 16,8 & \\
\hline Özel Hastane & 10 & 28,6 & 8 & 22,9 & 11 & 31,4 & 6 & 17,1 & \\
\hline Özel Muayenehane & 0 & 0,0 & 1 & 50,0 & 0 & 0,0 & 1 & 50,0 & \\
\hline \multicolumn{10}{|l|}{ Sağlık Değerlendirmesi } \\
\hline Mükemmel & 2 & 16,7 & 0 & 0 & 8 & 66,7 & 2 & 16,7 & \multirow{5}{*}{$<0,001$} \\
\hline Oldukça İyi & 10 & 20,4 & 6 & 12,2 & 16 & 32,7 & 17 & 34,7 & \\
\hline İyi & 23 & 15,6 & 62 & 42,2 & 45 & 30,6 & 17 & 11,6 & \\
\hline Fena Değil & 45 & 32,8 & 49 & 35,8 & 32 & 23,4 & 11 & 8,0 & \\
\hline Kötü & 20 & 46,5 & 17 & 39,5 & 5 & 11,6 & 1 & 2,3 & \\
\hline \multicolumn{10}{|l|}{ Kronik Hastalık } \\
\hline Evet & 66 & 30,8 & 87 & 40,7 & 41 & 19,2 & 20 & 9,3 & \multirow[t]{2}{*}{$<0,001$} \\
\hline Hayır & 34 & 19,5 & 47 & 27,0 & 65 & 37,4 & 28 & 16,1 & \\
\hline \multicolumn{10}{|c|}{$\begin{array}{l}\text { Düzenli İlaç Kullanımı Gerektiren } \\
\text { Hastalık }\end{array}$} \\
\hline Var & 66 & 28,7 & 83 & 36,1 & 59 & 25,7 & 22 & 9,6 & \multirow[t]{2}{*}{0,092} \\
\hline Yok & 34 & 21,5 & 51 & 32,3 & 47 & 29,7 & 26 & 16,5 & \\
\hline
\end{tabular}

Tablo 4. Katıımcıların sağlık okuryazarlığı düzeyleri üzerinde etkili değişkenlerin çoklu analizle değerlendirilmesi.

\begin{tabular}{llll}
\hline & OR & \%95 GA & $p$ \\
\hline Yaş & 0,952 & $0,957-0,978$ & $<0,001$ \\
Dul/Boşanmış/Ayrı & - & & \\
Evli & 3,599 & $1,116-11,607$ & 0,032 \\
Bekar & 4,410 & $1,179-16,497$ & 0,027 \\
Köy & - & & \\
Kasaba & 1,834 & $0,774-4,343$ & 0,168 \\
İlçe & 2,156 & $0,865-5,374$ & 0,099 \\
II & 4,896 & $1,614-14,848$ & 0,005 \\
Gelir Giderden Az & - & & \\
Gelir Gidere Eşit & 1,639 & $0,940-2,858$ & 0,082 \\
Gelir Giderden Fazla & 3,098 & $1,571-6,111$ & 0,001 \\
Kötü & - & & \\
Mükemmel & 29,687 & $4,341-203,000$ & 0,001 \\
Oldukça İyi & 8,537 & $2,580-28,256$ & $<0,001$ \\
İyi & 4,385 & $1,502-12,803$ & 0,007 \\
Fena Değil & 4,120 & $1,374-12,354$ & 0,012 \\
\hline
\end{tabular}

*Modele yaş, cinsiyet, medeni durum, öğrenim düzeyi, çalışma durumu, en uzun süre yaşanılan yer, gelir durumu, başvurulan poliklinik, ayda ortalama başvuru sayısı, sağlık değerlendirmesi, kronik hastalık varlığı değişkenleri dahil edilip lojistik regresyon analizi (backward) yapılmıştır.

${ }^{* *}$ Nagelkerke $R^{2}: 0,36$ 
faktörleri incelediğimizde yaş, il merkezinde yaşayanların, geliri giderinden yüksek olan bir sosyoekonomik algıya sahip olanların ve kendi sağlığını mükemmel olarak değerlendirenlerin sağlık okuryazarlık düzeyleri diğerlerinden yüksek saptanmıştır. Özkan ve ark. HLSEU kullanarak 2139 kişi üzerinde yaptığı genel araştırma verilerinde, her 4 kişiden 3'ünde $(\% 73,5)$ sınırlı (yetersiz/sorunlu) sağlık okuryazarlığı olduğunu, \%30,5' inin yetersiz ve \%43,0'ünün sorunlu-sınırlı sağlık okuryazarlığı olduğunu tespit etmişlerdir. Çoklu analizler göstermiştir ki; sınırlı sağlık okuryazarlığı düzeyleri daha çok yaşlı kesimde, düşük eğitim düzeyinde ve düşük ekonomik seviyede görülmektedir [9]. Başkent Üniversitesi'nde 303 hasta ile yapılan bir tez çalışmasında, yaş ortalaması $46,21 \pm 15,76$, yarısından fazlasının evli $(\% 72,2)$ ve kadın $(\% 67,6)$ olduğu bulunmuştur. Büyük çoğunluğu sağlığını iyi/ çok iyi ve mükemmel olarak değerlendirirken, \%68,9'u tanı konulmuş bir hastalığı olduğu, sağlık okuryazarlığı durumlarının genel olarak yüksek olduğu belirtilmektedir. Aynı çalışmada okuryazar olmayanların, sadece okuma yazma bilenlerin, geliri giderinden az olan bir sosyoekonomik algıya sahip olanların, kendi sağlık düzeylerini kötü/çok kötü olarak ifade edenlerin, Genel Sağlık Anketine (GSA) göre yüksek riskli gruptaki hastaların sağlık okuryazarlığı ile ilgili puanlarının diğer hastalardan daha düşük olduğu bulunmuştur [10]. Bizdeki, demografik veriler ve sağlık okuryazarlığı puan ortalamaları açısından kısmen benzerlik göstermektedir. Yurt dışı kaynaklı çalışma 8 Avrupa (İrlanda, Almanya, Avusturya, Bulgaristan, Hollanda, Polonya, İspanya, Yunanistan) ülkesinde gerçekleşen 12 alt başlık ve 47 sorudan oluşan sağlık okuryazarlığı ölçümleri, Hollanda'yı \%29, Bulgaristan'ı \%62 oranında yetersiz/sorunlu bulurken, Bulgaristan'ın \%37'sini ve İspanya'nın \%42'sinin yeterli ve çok iyi bulduğunu ilan etmiştir [11]. Tunceli ilinde TSOY-32 kullanılarak yapılan bir araştırmada; katılımcıların \%11,8'i $(n=47)$ yetersiz, \%43,0'ü $(n=173)$ sorunlu, \%28,8'i (n=115) yeterli, \%16,5 'i $(n=66)$ mükemmel düzeyde sağlık okuryazarlığı düzeyinde olduğu gösterilmiştir. Aynı çalışmada sağlık okuryazarlık düzeyinin eğitim düzeyi ve gelir durunu arttıkça arttığı, yaş arttıkça azaldığı belirlenmiştir (sırasıyla $p<0,001$, $p=0,046, p<0,001)$. Kronik hastalığı olanların, 65 yaş üzeri bireylerin ve sosyal güvencesi olmayanların sağlık okuryazarlık düzeyi daha düşük saptanmıştır (sırasıyla $p=0,001, p=0,001$, $p=0,010)$. Bu sonuçlar bizim araştırmamıza göre bazı yönlerden benzemekte olup, sınırı/ sorunlu sağlık okuryazarlığı açısından daha iyi bulunmuştur [12]. Kronik hastalık olma durumu çalışmamızda regresyon modeline alınmış fakat istatistiksel anlamlılık tespit edilmemiştir. İstanbul ilinde Avrupa Sağlık Okuryazarlığı Ölçeği Türkçe Uyarlaması (ASOY-TR) ile yapılan çalışmada; kadınların \%22'si yetersiz, \%42,4'ü sorunlu/sınırlı, \%35,6'sı yeterli sağlık okuryazarlığına sahip iken, erkeklerin \%21,3'ü yetersiz, \%40,4 sorunlu/sınırlı \%38,3'ü yeterli sağlık okuryazarlığı düzeyinde tespit edilmiş ve toplam olarak \%37'sinde yeterli sağlık okuryazarlığı bildirilmiştir. Sağlık okuryazarlığı, cinsiyet, eğitim durumu, gibi bağımsız değişkenler arasında istatistiksel olarak anlamlı ilişki saptanmamıştır. Araştırmamız her ne kadar ASOY-TR ile yapılmamış olsa da, cinsiyetle sağlık okuryazarlığı arasında istatistiksel fark bulunmazken, eğitim durumuyla hem ki-kare analizi hem de regresyon modeli ile anlamlılık göstermiştir [13]. Yukarıkır ve ark. tarafından, yüz yüze anket tekniğiyle yapılan hastalara sosyo-demografik özelliklerini ve tıbbi geçmişini içeren 10 soru, sağlık okuryazarlığını değerlendiren ve uluslararası ölçekleri içeren 10 soru ve sağlık hizmetlerinden faydalandığı sıradaki davranışlarını içeren üç sorudan oluşan anket formuyla yapılan çalışmada; gelir düzeyi, öğrenim düzeyi arasında anlamlı farklılık görülmüş, cinsiyetin, yaşın, kronik hastalığı olma durumunun sağlık okuryazarlığı düzeyi ile bir ilişkisinin olmadığı bulunmuştur. Bu hali ile bizdeki sonuçlarla benzerlik göstermektedir. Her iki araştırmanın da üniversite hastanesinde yapılmış olması bu durumu yaratmış olabilir [14].

Güçlü yanlar: Çalışmanın dahiliye polikliniklerinde yapılmasına karar vermek, hasta yoğunluğunun durumu, kronik hastalık başvurularının çok daha sık olması ve üniversitede hastanesinde geneli içeren hastalara tanı olanağı sağlaması açısından sağlık okuryazarlığı düzeyini belirlemekte doğru bir ilk adımdı. Bu güçlü yanımızdı.

Kısıtlıklar: Çalışmanın sadece İç Hastalıkları polikliniği başvuranları ile sınırlı kalması kısıtılığımızı oluşturdu. 
Sonuç olarak; bu çalışmada iç hastalıkları polikliniğine herhangi bir sebepten dolayı başvuranların TSOY-32 ölçeğine göre sorunlusınırlı sağlık okuryazarlığı düzeyinde olduğunu ve sağlık okuryazarlığı düzeyinin yaş, en uzun süre yaşanılan yer, gelir algısı durumu, kendi sağlık düzeyi algısı gibi kimi bağımsız değişkenlerden etkilendiğini bulduk.

Günümüzde bireylerin sağlıkla ilgili mesajları doğru anlayabilmelerinin ve kendi sağlık durumları hakkında yeterli biligiye sahip olabilmelerinin ve tedavi başta olmak üzere bazı hayati uygulamaları başarı ile yapabilmelerinin ön koşulun sağlık okuryazarlığı düzeyini artırmak olduğu görüşündeyiz.

Toplumun yapısına uygun örneklerle; örgün eğitimde sağlık bilincine erişmek, genç kuşaklar arasında akran eğitimine önem vermek, sağlık çalışanları başta olmak üzere hastane çalışanlarında sağlık iletişim becerilerini geliştirmek gibi faaliyetlerin; ülke genelinde sağlık okuryazarlık düzeyine etki edeceğine inanıyoruz. Bu konuda başarının anahtarının sağlık çalışanlarında olduğu kadar politika yapıcılarının olduğunu da hatırlatmak isteriz.

Çıkar ilişkisi: Yazarlar çıkar ilişkilerinin olmadığını beyan ederler.

\section{Kaynaklar}

1. Sorensen K, Pelikan JM, Röthlin F, et al. Health literacy in Europe: comparative results of the European health literacy survey (HLS-EU). Eur J Public Health. 2015;25:1053-1058. https://doi.org/10.1093/eurpub/ ckv043

2. Göçmen L, Kankılıç M, Demirbaş AR, Akçay E, Zaralı F, Dede S. T.C. Sağlık Bakanlığı Temel Sağlık Hizmetleri Genel Müdürlüğü, Sağlığın teşviki ve geliştirilmesi sözlüğü Anıl Matbaacılık 1. Baskı, Ankara, 2011.

3. Kickbusch I, Pelikan JM, Apfel F, Tsouros AD. WHO health literacy: the solid facts, WHO Regional Office for Europe UN City, Marmorvej 51 DK-2100 Copenhagen, Denmark, 2013, ISBN: 9789289000154.

4. Weiss BD. Health literacy and patient safety: help patients understand. Manual for clinicians. 2nd ed. Chicago, AMA Foundation, 2007.

5. Durusu Tanrı̈̈ver M, Yıldırım HH, Demiray-Ready FN, Çakır B, Akalın HE (2014). Türkiye sağlık okuryazarlığı araştırması, Birinci Baskı, Sağlık-Sen Yayınları, Ankara.-

6. Glasgow RE, Orleans CT, Wagner EH, Curry SJ, Solberg LI. Does the chronic care model serve also as a template for improving prevention? Milbank $Q$ 2001;79:579-612.
7. TÜiK; İl, yaş grubu ve cinsiyete göre nüfus, 2007-2017.

8. Okyay $P$, Abacıgil F. Türkiye sağlık okuryazarlığı ölçeği-32 (TSOY-32). Okyay P, Abacıgil F, Editörler. Türkiye Sağlik Okuryazarliği Ölçekleri Güvenilirlik ve Geçerlilik Çalişmasi. 1. Baskı. Sağlık Bakanlığı Yayın No: 1025. ISBN: 978-975-590-594-5. Ankara. Anıl Reklam Matbaa. 2016;43-62.

9. Ozkan S, Dikmen AU, Tuzun H, Karakaya K. Prevalence and determiners of health literacy in Turkey, Eur J Public Health 2016;26. https://doi. org/10.1093/ eurpub/ckw175.072

10. Uğurlu Z. Sağlık kurumlarına başvuran hastaların sağlık okuryazarlığının ve kullanılan eğitim materyallerinin sağlık okuryazarlığına uygunluğunun değerlendirilmesi. Doktora Tezi. Başkent Üniversitesi Sağlık Bilimleri Enstitüsü, Ankara 2011. Erişim adresi: https://docplayer.biz.tr/18109437-Baskent-universitesisaglik-bilimleri-enstitusu-halk-sagligi-anabilim-dali. html. Erişim tarihi 19.07.2019

11. Bilir N. Sağlık okuryazarlığı. Turk J Public Health 2014;12:61-68 https://doi.org/10.20518/thsd.46492

12. Önal AE, Bozbuğa Ulusoy N, Akyurt Aydın LE, Şeker N, Gül H. İki kamu kurumu çalışanlarında sağlık okuryazarlığı. 19. Ulusal Halk Sağlığı Kongresi, Antalya, Halk Sağlığı Barışa Köprü 2017;438.

13. Yukarıkır N, Özvarış ŞB, Güçiz Doğan B, ve ark. Bir üniversite hastanesi polikliniklerine başvuranlarda sağlık okuryazarlığının değerlendirilmesi. 18. Ulusal Halk Sağlığı Kongresi Konya, 2015;814-815. Erişim adresi: https://drive.google.com/open?id=1Qtn3Ck8Ck ALSndtarKfrS_5mp3KgeAzD. Erişim tarihi 05-09 Ekim 2015

14. Özaydın S, Güneşli Özdemir S, Aktaş H, Mercan V, Ataç $\mathrm{K}$. Tunceli merkezde 18 yaş ve üzeri bireylerde sağlık okuryazarlığı prevalansı ve ilişkili faktörler. 2 . Uluslararası 20. Ulusal Halk Sağlığı Kongresi Antalya, Kongre Kitabı 2018;271-273.

Teşekkür: Katkılarından dolayı Osman Gazi Sağlam, Rıdvan Khasonov, Gülsüm Akkeçeli, Saniye Küçükakın, Sinem Karaarslan, Özge Özden, Halil İbrahim İnanöz, Muzaffer Yüce, Emre Dere, Alperen Halil Hayla, Halil Sevimli, Mustafa Kaya ve Salih Keskin'e teşekkür ederiz.

2. Uluslararası 20. Ulusal Halk Sağlığı Kongresi'nde poster bildiri olarak sunulmuştur.

Etik kurul onayı: Pamukkale Üniversitesi Girişimsel Olmayan Klinik Araştırmalar Etik Kurulu'ndan 26/07/2018 ve 60116787020/50510 sayı ile onay alınmıştır. 